\title{
THE CURIOUS CASE OF THE MARGINALISATION OR DISTORTION OF RUSSIAN AND SOVIET ENVIRONMENTAL HISTORY IN GLOBAL ENVIRONMENTAL HISTORIES
}

\section{Abstract}

For too long, 'global environmental history' has not been truly 'global', but has been shaped by the perspectives and linguistic skills of its practitioners, who have generally, but not solely, been based in the Anglophone world. This is evident until recently in the relatively limited consideration of the environmental history of Russia and the Soviet Union-the largest country in the world-in works on global environmental history, and in the distorted or unbalanced treatment of that country's environmental history in such works. The article first briefly reviews 'global environmental history', and then considers how and why so many global environmental histories have marginalised or distorted Russian environmental history. It points to reasons relating to language, periodisation and biases. The essay concludes by assessing the prospects for further integration of Russian environmental history into global histories.

Keywords: Russia, Soviet Union, environmental history, global history, world history, empires, environmental disasters

\section{Introduction}

The purpose of this article is to consider the curious case of the marginalisation or distortion of the environmental history of Russia and the Soviet Union in works on world or global environmental history. The article covers a selection of such studies in English or translated into English. It will provide insights into how

1 david.moon@york.ac.uk. The author would like to acknowledge the support of the Rachel Carson Center for Environment and Society, Ludwig-Maximilian University, Munich, and the Leverhulme Trust. He is grateful also to the editor and two anonymous reviewers for their constructive suggestions. 
environmental historians of other parts of the globe, who do not read specialist works on the subject or Russian-language sources, perceive 'Russian environmental history'. After a brief overview of 'global environmental history', this article then discusses how many global environmental histories have marginalised or excluded Russia. In those that have included it, however, the 'traditional interpretation' has been to make a case for Russian exceptionalism with massive, state-sponsored environmental degradation, especially during, but not limited to, the Soviet period of Communist Party rule (1917-91). Over time, more balanced interpretations have emerged. In part, these have presented longer-term perspectives, moving back before the Soviet period. An important part has been played by the integration of different voices from specialist Russian environmental historians, in particular Russian scholars. The article concludes by assessing the prospects for further integration of Russian environmental history in global histories.

\section{Global environmental history}

From the earliest days of environmental history as a specialist field of historical enquiry, environmental historians have looked beyond the borders of nation-states to encompass larger parts of the world. Nevertheless, to a large but not exclusive extent, researching and writing 'global environmental history' has been a US- and Anglocentric endeavour, fuelled in part by the global reach of American academic studies and the legacy of Britain's global empire. Alfred Crosby's pioneering and ambitious studies of the Columbian exchange and ecological imperialism, published in the 1970s and 1980s, located the environmental history of the Americas, Australasia and Europe in the wider contexts of much of the globe and deep time. ${ }^{2}$ The first generation of practitioners of American environmental history wrote about national parks, the American West and 'wilderness'; created a 'pantheon of [American] environmental heroes', from George Perkins Marsh to Rachel Carson; and constructed a declensionist narrative to explain how the 'pristine wilderness' of much of the United States had been transformed by people, in particular the immigrants who populated its lands from the sixteenth and seventeenth centuries, through agriculture and industry, driven by capitalism. ${ }^{3}$ On the other side of the Atlantic, the British scholar Richard Grove pointed to the growing awareness of human impact on environments, and to efforts to study and remedy it, in the experience of (western) European colonialism, first on Atlantic and tropical islands,

2 Alfred W. Crosby, The Columbian Exchange: Biological and Cultural Consequences of 1492 (Westport, CT: Greenwood Press, 1972); Alfred W. Crosby, Ecological Imperialism: The Biological Expansion of Europe, 900-1900 (New York: Cambridge University Press 1986).

3 See Douglas Cazanaux Sackman, 'Introduction', in A Companion to American Environmental History, ed. Douglas Cazanaux Sackman (Malden, MA, and Oxford: Wiley-Blackwell, 2010), xiii-xxi, and the works cited therein. 
and later on land masses around the globe. ${ }^{4}$ The 'cultural turn' that stimulated research across the humanities from the 1980s to some extent divided the field of environmental history into those primarily concerned with the 'so-called material dimensions of history' and others interested in 'changing ideas about the natural world' with a focus on representation and culture; however, some scholars have drawn on both strands. ${ }^{5}$ Environmental historians, together with other historians, have long found race, gender and class to be useful categories of historical analysis. The development of the sub-discipline of environmental history in Asia, Australasia, Europe and South and Central America, in each case drawing on differing academic traditions, has made it truly global in its scope and reach, and created a global pool of expertise on which genuinely global environmental histories can draw. ${ }^{6}$

As environmental history and those practising it have spread around the globe, an increasing number of monographs and edited collections of essays have been published that cover, or more accurately claim to cover, much or all of the globe. How has the environmental history of Russia and the Soviet Union been presented in these global environmental histories? This is quite important, since the Russian Empire from the early eighteenth century to 1917, the Soviet Union down to 1991, and the post-Soviet Russian Federation were or are the largest states on earth, at their greatest extent covering a sixth of its land surface. This was a result of expansion from a core territory around Moscow from the sixteenth century to cover much of eastern Europe and northern Asia until the break-up of the Soviet Union allowed the emergence of independent states surrounding a rump, but still vast, Russian Federation. These lands encompass a range of environmental regions from tundra in the north, through successive belts of boreal forest, mixed forest, forest-steppe, steppe and desert, with mountain ranges on the southern and eastern peripheries. This vast territory contains some of the world's longest rivers, such as the Volga and Lena, and major lakes, perhaps the most well known being the ill-fated Aral Sea and the ecological gem of Baikal. The territory also contains an abundance of natural resources, including vast forests, fertile soils, fur-bearing animals, valuable metal ores and fossil fuels, especially large reserves of oil and gas. Some of these resources, however, are located in areas fairly inaccessible from the core territory. The inhabitants are and have been peoples of many ethnicities (Slavic, Finnic, Tatar, Mongol and others), faith traditions (including Orthodox Christianity, Islam, Buddhism, Judaism, Shamanist beliefs and atheism) and lifeways (nomadic and settled, rural and urban, agricultural, industrial, post-industrial). For much of their history, moreover, these lands have been ruled by a variety of political systems that

\footnotetext{
4 Richard Grove, Green Imperialism: Colonial Expansion, Tropical Island Edens and the Origins of Environmentalism, 1600-1860 (Cambridge: Cambridge University Press, 1995).

5 See Sackman, 'Introduction', xiv.

6 The International Consortium of Environmental History Organizations, which held its first congress in 2009, seeks to 'foster international communication among environmental history organizations'. www.iceho.org/missionstatement-2, accessed August 2017.
} 
have prioritised the power of the state over individuals, in particular the power of autocratic tsars and Communist Party leaders before and after 1917. These lands thus provide extremely fertile grounds to test differing understandings of humannature relationships and entanglements. ${ }^{7}$

And yet, the environmental history of the Russian and Soviet lands has tended to be under-represented or distorted in global environmental histories. We will return to reasons for this later (see the conclusion below). In the meantime, we can trace how the environmental history of the Russian and Soviet lands has been represented.

\section{Russia marginalised or excluded}

Most frustratingly, the authors and editors of some studies of global environmental history have chosen to focus on other parts of the world and paid little attention to the world's largest state and its fascinating and multifaceted environmental history. It seems invidious to single out examples, but without implying criticism of authors and editors who had difficult choices to make in selecting what to cover, a recent environmental history of the middle ages made one brief reference to 'Russia' concerning the use of horse power by Scythians who lived in 'Southern Russia' (in terms of present-day borders, mostly Ukraine). ${ }^{8}$ The author of an essay reviewing 'Non-US Historiographies' in a volume on American environmental history chose to focus his analysis on South Asian, African and comparative environmental histories, to the exclusion of studies of Europe, Australasia and Latin America. The author was open in explaining that his choice reflected what he found intriguing, the literature he was more exposed to, and what he thought would be useful for American environmental historians. He also focused on literature available in English. ${ }^{9}$ It is to be hoped that in the future authors of similar essays would choose to focus on 'Russian environmental history' for the same reasons this author made his selections.

Most, but not all, environmental histories of European colonialism and imperialism have concentrated on western Europe's overseas maritime colonies rather than the outlying parts of the land empires of Russia and other eastern European polities. Crosby considered the extent to which Siberia - annexed and colonised by Russia west of the Ural mountains from the late sixteenth century—-fitted his interpretation of 'neo-Europes' colonised by European powers in temperate parts of the world, but

\footnotetext{
7 See David Moon, 'Peasant Migration and the Settlement of Russia's Frontiers 1550-1897', Historical Journal 40 (1997), 859-93, doi.org/10.1017/s0018246x97007504; David Moon, 'Land and Environment', in The Oxford Handbook of Modern Russian History, ed. Simon Dixon (Oxford: Oxford University Press, forthcoming). Online publication date: March 2015, doi.org/10.1093/oxfordhb/9780199236701.013.001.

8 John Aberth, An Environmental History of the Middle Ages: The Crucible of Nature (London and New York: Routledge, 2013), 150.

9 Paul Sutter, 'Seeing Beyond Our Borders: US and Non-US Historiographies', in Sackman, A Companion to American Environmental History, 635-52.
} 
concluded that it did not fit. ${ }^{10}$ The Eurasian steppe to the south, however, much of which was also colonised by Slavic peoples from the Russian and Polish states from the sixteenth century, may offer more intriguing parallels with Crosby's 'neoEuropes'. ${ }^{11}$ Grove's topic was the origins of environmentalism in western Europe's overseas colonies and made only very brief mention of Russia; ${ }^{12}$ however, applying his interpretation to Russia's land empire is stimulating. ${ }^{13}$ More recently, building on the large literature on the environmental history of western Europe's overseas empires that has appeared since Crosby's and Grove's pioneering works, Corey Ross has made a considerable contribution to our understanding of European imperialism as a 'socio-ecological endeavour' in his monograph on 'Europe and the transformation of the tropical world' (my emphasis). ${ }^{14}$ Ross's book, therefore, and many other studies of the ecology of European empires exclude Russia's temperate and arctic empire, but set a high standard for environmental historians of Russia's empire to emulate. An impressive global history of empire that does include Russian and Eurasian empires, but addresses issues other than environmental history, was produced a few years ago by Jane Burbank and Frederick Cooper. ${ }^{15}$

\section{Russian exceptionalism? Massive state- sponsored environmental degradation?}

Another trend, or perhaps distortion, in the representation of Russian and Soviet environmental history in global environmental histories has been to use these lands as an example of massive, state-sponsored environmental degradation fuelled by careless and wasteful exploitation of natural resources by authoritarian states. (Some scholars have also considered communist China together with the Soviet Union.) A litany of Soviet environmental disasters, actual or narrowly averted, is presented as if part of a moral lesson for the rest of world of what can go wrong without due care for the natural world: massive pollution or degradation of the land, air and water, and harm to human health, as a result of rapid, centrally planned industrial and agricultural development; the conversion of free-flowing rivers to chains of lakes by big dams; the threat to the pristine waters and unique ecosystem of Lake Baikal from cellulose plants built on its shores; the drying-up of the Aral Sea in Central Asia as a result of the diversion of waters from the rivers

10 Crosby, Ecological Imperialism, 36-9.

11 David Moon, The Plough that Broke the Steppes: Agriculture and Environment on Russia's Grasslands, 1700-1914

(Oxford: Oxford University Press, 2014), 22.

12 Grove, Green Imperialism, 320-1.

13 Moon, Plough, 22-3.

14 Corey Ross, Ecology and Power in the Age of Empire: Europe and the Transformation of the Tropical World (Oxford: Oxford University Press, 2017).

15 Jane Burbank and Frederick Cooper, Empires in World History: Power and the Politics of Difference (Princeton, NJ: Princeton University Press, 2010). 
feeding it to irrigate the surrounding arid lands to cultivate cotton; an aborted plan, following warnings from scientists, to divert rivers from Siberia and the Far North to replenish it; and above all the catastrophic explosion at the Chernobyl nuclear power station, as a result of design flaws and a test that went disastrously wrong. The last has become a symbol of the Soviet Union as an environmentalcatastrophe state. All the items on this list are sadly true, but may not present a fully rounded and balanced interpretation of the environmental history of these lands. Some global environmental histories that focus on these negative aspects present the Russian/Soviet case as a worst-case scenario. Others are more careful to examine the Russian/Soviet experience in a comparative perspective.

In many of these global environmental histories focusing on the negative aspects, the authors do not know Russian and have relied on secondary literature available in English and other western European languages which are more widely known among Western scholars of global environmental history. To some extent, therefore, their interpretations are based not on original research and deep knowledge of the subject, but have perhaps been influenced, no doubt partly subconsciously, by longstanding Western stereotypes of Russian 'barbarity' and 'backwardness' that were only exacerbated by the onset of Communist Party power after 1917 and the Cold War after 1945, and can all too readily be found in recent international media coverage of matters concerning Russia. ${ }^{16}$

Again, without wishing to imply criticism of authors who have sought to synthesise a wide range of literatures on a broad array of subjects and parts of the globe, a few examples can illustrate this trend. Clive Ponting's Green History of the World (1991) included a standard statement of how rapid Soviet industrialisation, based on targets aimed to maximise output with little regard for the environment, had negative consequences, and took examples from the Soviet Union to support his interpretation of 'The Environment and the Collapse of Major Civilizations'. ${ }^{17}$ In his study of how societies choose to fail or succeed, informed by how they have used or abused the environment, Jared Diamond did not cover the Soviet Union in detail, but mentioned it in his wider analysis:

one of the main lessons to be learned from the collapse of the Maya, Anasazi, Easter Islanders, and those other past societies (as well as from the recent collapse of the Soviet Union) is that a society's steep decline may begin only a decade or two after the

16 For analyses of such perceptions, see Lloyd E. Berry and Robert O. Crummey, Rude and Barbarous Kingdom: Russia in the Accounts of Sixteenth-Century English Voyagers (Madison, WI: University of Wisconsin Press, 2012) [reprint: first published 1968]; Marshall T. Poe, 'A People Born to Slavery': Russia in Early Modern European Ethnography, 1476-1748 (Ithaca, NY: Cornell University Press, 2000); Larry Wolff, Inventing Eastern Europe: The Map of Civilization on the Mind of the Enlightenment (Stanford, CA: Stanford University Press, 1994); Martin Malia, Russia under Western Eyes: From the Bronze Horseman to the Lenin Mausoleum (Cambridge, MA: Belknap Press of Harvard University Press, 1999).

17 Clive Ponting, A New Green History of the World: The Environment and the Collapse of Great Civilizations, new revised ed. (London: Penguin, 2007), 358. 
society reaches its peak numbers, wealth, and power. In that respect, the trajectories of the societies that we have discussed are unlike the usual courses of individual human lives, which decline in a prolonged senescence. The reason is simple: maximum population, wealth, resource consumption, and waste production mean maximum environmental impact, approaching the limit where impact outstrips resources. On reflection, it's no surprise that declines of societies tend to follow swiftly after their peaks. ${ }^{18}$

The recent Oxford Handbook of Environmental History, written mostly by American or American-educated or based scholars, does not do full justice to the complex entanglement of humans in the wider environment in the Russian/Soviet space. The index entries for 'Russia' and the 'Soviet Union' convey the extent and balance of the coverage of the world's largest country: 'Mongol invasion; plunder of natural resources in; private property in; Steppes, settlement of; environmental management lacking in; ideal masculine images in; nature protection in; weather modification in'. ${ }^{19}$ The essay on 'The Politics of Nature' by Frank Zelko sets out its stall unambiguously. The author wrote about the emergence of powerful, totalitarian states that controlled vast territories: the Soviets in Russia, the Nazis in Germany and Mao's communists in China. He suggests: 'There was little political space and few resources for the type of environmental management that was occurring in Western democracies.' Further: 'The Soviet and Chinese states were concerned with wringing natural resources and food from the land as quickly as possible, with little thought for conservation, let alone nature preservation, wildlife protection, or concerns about pollution.' He noted that although there were a few environmentally-minded scientists in the Soviet Union, the situation in communist China was 'similarly bleak'. He continued: 'In both these states, environmental management, if one can call it that, was devoted to intensive exploitation regardless of the ecological and social costs.' The author's background as a historian of Greenpeace may have inclined him against large, authoritarian states. ${ }^{20}$ Elsewhere in the volume, however, James Morton Turner presents a more balanced discussion of nature protection in the Soviet Union in an essay rethinking American exceptionalism. ${ }^{21}$

A further explanation for the rather one-sided treatment of Russian/Soviet environmental history in global environmental histories, besides lack of linguistic skills to read Russian for research and inherent if sometimes unconscious bias, is that global environmental historians have engaged in a partial reading of specialist

18 Jared Diamond, Collapse: How Societies Choose to Fail or Succeed (New York: Viking Penguin, 2005), 509.

19 Andrew C. Isenberg, ed., The Oxford Handbook of Environmental History (New York: Oxford University Press, 2014), 774, 777.

20 Frank Zelko, 'The Politics of Nature', in The Oxford Handbook of Environmental History, ed. Isenberg, 728, 737 n. 16 .

21 James Morton Turner, 'Rethinking American Exceptionalism', in Isenberg, The Oxford Handbook of Environmental History, 291. 
works in English, and that some of this literature, especially early studies of the subject, present precisely the negative interpretation that has made its way into global environmental histories.

A major landmark in Western scholarship on Russian and Soviet environmental issues was the book by the American specialists Murray Feshbach and Alfred Friendly, Ecocide in the USSR: Health and Nature under Siege, published in 1992 in the immediate aftermath of the end of the Soviet Union. ${ }^{22}$ The book was a massive indictment of the mismanagement and abuse of the environment in the Soviet Union that had led to an ecological disaster-ecocide-which, in turn, had had a serious, negative influence on the health of the Soviet population, demonstrated by declining life expectancy. The book is a catalogue of waste, pollution, environmental and human health disasters, including the drying-up of the Aral Sea, factories pumping pollutants into the atmosphere of industrial areas such as Kemerovo in Siberia, and the escalating incidence of cancer and respiratory and digestive diseases. The authors traced the origins of the problem to Stalin's Five-Year Plans and massive engineering projects that prioritised production targets over due care for the health of the environment and the population. At one point the authors went so far as to state that the Soviet Union experienced 'ecocide by deliberate design'. ${ }^{23}$ They also argued that ecocide was a factor in the demise of the Soviet Union. Feshbach and Friendly did make comparative points: they pointed out that controls on pollution in the United States were much more effective than in the Soviet Union, but accepted that the United States had serious levels of pollution in some areas, and in cases was worse than the Soviet Union. But they did not sustain the comparison. The book was very influential. In the Environmental History Review, the prominent scholar Mark Tauger wrote:

While Ecocide in the USSR focuses on what may be the worst case of 'ecocide' in history, it serves as a warning of the threat that pollution and ecological disruption represent to human health in any political system. This book is essential reading for environmental and Soviet specialists. It could be used in a variety of environmental and general history classes. ${ }^{24}$

The legacy of Feshbach's and Friendly's interpretation and similar studies can be found in the treatment of Soviet environmental history in the works on global environmental history considered thus far.

The negative, declensionist interpretation of Soviet environmental history has also been presented effectively and to wider readerships by the American scholar Paul Josephson, whose long-standing expertise in the history of science and technology

22 Murray Feshbach and Alfred Friendly, Ecocide in the USSR: Health and Nature under Siege (New York: Basic Books, 1992).

23 Feshbach and Friendly, Ecocide, 75.

24 Review by Mark B. Tauger, Environmental History Review 16, no. 3 (1992): 95-7. 
in the Soviet Union has given him considerable insights into the subject. His essay, 'War on Nature as Part of the Cold War: The Strategic and Ideological Roots of Environmental Degradation in the Soviet Union', opened a collection, edited by John McNeill and Corinna Unger, on the environmental history of the Cold War. Josephson's position is clear: 'The Soviet environmental legacy is fields of toxic waste'; the 'war on nature' in the Soviet Union was distinguished by interrelated political, economic and ideological factors; and the 'assault' was accelerated in the Cold War. ${ }^{25}$

The arguments presented by Josephson, Feshbach and Friendly, and others making a strong, negative case for the impact of Soviet economic policies on the environment that have made their way into global environmental histories are, it should be emphasised, legitimate and based on careful and rigorous research into an array of sources. It is not the purpose of this article to challenge their veracity. What may be questioned, however, is how far the Soviet experience was extreme, an outlier, or one part of a wider global experience of environmental degradation in industrialising and industrialised parts of the world. ${ }^{26}$ It may also be asked how far the negative interpretation of Soviet environmental disasters and degradation may realistically be presented as the most important or largest part of the environmental history of the territory of the Soviet state. Or are there other aspects that need to be presented to give a more balanced picture? ${ }^{27}$ Whatever answers may be given to these two questions, a third question that has recurred in the representation of Russian and Soviet environmental history in global environmental histories is the extent to which the Soviet experience was peculiar to the twentieth century, or whether it had deeper roots in Russian and Eurasian history. Possible answers to the first two questions will be suggested later in the analysis of more recent global histories. Regarding the third one, two major scholars with particular expertise on Russia whose work has reached global history audiences have made strong cases for longer-term origins of humaninduced environmental degradation in this part of the world dating back centuries.

David Christian, in his 'Big History', developed the earlier idea of 'tribute-taking societies', dating back to the fourth millennium BCE, in which 'elite groups used force or the threat of force to control surplus resources'. Such societies, he argued, 'have been the most powerful and most visible communities for most of recorded

25 Paul Josephson, 'War on Nature as Part of the Cold War: The Strategic and Ideological Roots of Environmental Degradation in the Soviet Union', in Environmental Histories of the Cold War, ed. J. R. McNeill and Corinna R. Unger (Cambridge: Cambridge University Press, 2010), 21-50; quotations from 21, 22. Josephson presented a similar interpretation at much greater length in a co-authored environmental history of Russia that focused mostly on the Soviet period: Paul Josephson, Nicolai Dronin, Ruben Mnatsakanian, Aleh Cherp, Dmitry Efremenko, Vladislav Larin, An Environmental History of Russia (New York: Cambridge University Press, 2013).

26 Josephson himself considered Soviet environmental history in a comparative perspective in his Industrialized Nature: Brute Force Technology and the Transformation of the Natural World (Washington, DC: Island Press, 2002).

27 See Jonathan Oldfield, Julia Lajus and Denis J. B. Shaw, 'Introduction', in 'Conceptualizing and Utilizing the Natural Environment: Critical Reflections from Imperial and Soviet Russia', special issue, Slavonic and East European Review 93, no. 1 (2015): 1. 
history. He went on to argue that many characteristics of traditional tributary empires survived in 'great Communist empires of the twentieth century'. First in Russia, then in China, states with communist, anti-capitalist ideologies had to compete with capitalist states, but lacked the innovatory dynamism of capitalism. Communist states were better at mobilising resources than raising productivity through innovation, thus most of the increases in production were a result of coercive mobilisation of capital, raw materials and labour. The Soviet Union never caught up with the capitalist world, defied attempts at reform, eventually ran out of resources and collapsed. ${ }^{28}$

Working on the narrower temporal and spatial frameworks of the entire span of Russia's history, Douglas Weiner-one of the first American environmental historians of Russia-made a strong case for Russian/Soviet particularism over a long time period in an essay in a volume on the environment in world history. He referred to the Aral Sea, the Semipalatinsk nuclear testing site in Kazakhstan, and Chernobyl, amongst other sites of environmental disasters in Eurasia. Locating them in a longer-term context, he argued that Russian/Soviet environmental policy has been based on a long tradition of tribute-taking: 'since the Mongol-Tatar invasion of the thirteenth century, and particularly with the rise and expansion of the Muscovite state and, later, the Russian Empire and the Soviet Union, a succession of militarized, predatory tribute-taking regimes have dominated the Eurasian landmass.' Weiner continued: 'Unbounded by rule of law ... these regimes saw the population and the land over which they ruled as a trove of resources to be mined for the rulers' purposes', which varied between regimes and included 'defence of the true faith', the 'ingathering of the Russian ethnos' and the 'creation of a just, classless society'. 'In pursuit of these purposes,' Weiner argued, 'Russia's rulers have spared neither people nor land.' This 'predatory tribute-taking state' has made the land mass 'a treacherous patchwork quilt of poisoned lands ... air ... and water'. While his argument emphasised the 'extremely serious' environmental problems of this part of the world, he ended his essay by suggesting that we, i.e. Western scholars, take a look in the mirror, where the outlines of a sinister "convergence" have become distinctly more pronounced of late'. ${ }^{29}$ (Thus, Weiner raised, but did not address in this article, the comparative framework for analysing the environmental history of

28 David Christian, Maps of Time: An Introduction to Big History, with a new preface (Berkeley, CA: University of California Press, 2011) [1st ed. 2004], 278-82, 455-7.

29 Douglas R. Weiner, 'The Predatory Tribute-Taking State: A Framework for Understanding Russian Environmental History', in The Environment and World History, ed. Edmund Burke III and Kenneth Pomeranz (Berkeley, CA: University of California Press, 2009), 276-315, quotations from 276, 277. An earlier version of the essay appeared as 'The Genealogy of the Soviet and Post-Soviet Landscape of Risk', in Understanding Russian Nature: Representations, Values and Concepts, ed. Arja Rosenholm and Sari Autio-Sarasmo (Aleksanteri Papers, 4) ([Helsinki]: [Aleksanteri Institute, University of Helsinki], 2005): 209-36. The similarity with Christian's argument seems a coincidence, as both were writing around the same time and did not cite each other in the original or later editions. 
the former Soviet lands.) One of the editors of the volume it appeared in, Kenneth Pomeranz, endorsed Weiner's interpretation in his introduction to the volume, referring to 'Russia's tragic environmental history'. ${ }^{30}$

Weiner's essay has become very influential in defining understandings of Russian/ Soviet environmental history in a wider, global context. It has been read as an authoritative or definitive summary of the topic. For example, in his review of the volume it appeared in, McNeill wrote: 'There is as yet nothing else that I know of that synthesizes the environmental history of ... Russia as well as ...Weiner's chapter. ${ }^{31}$ McNeill reprinted it in an introductory reader on global environmental history he edited. ${ }^{32}$ Weiner may, however, have intended his essay to make a case for a particular interpretation to provoke discussion and debate as his wider body of scholarship on Russian and Soviet environmental history is more nuanced and has focused on the Russian and Soviet tradition of scientific nature protection, works that have also been cited in global environmental histories.

Weiner presented a more balanced, but still declensionist, view of Soviet environmental history in an essay in a volume on environmental activism around the globe, which included case studies from the United States, western Europe, Australia, China, India, Mexico and Brazil, as well as Russia. He opened his essay by noting the surprised reaction from academics and laypeople alike when they heard he had written two books on Soviet environmental activism: 'Was there really an environmental movement in the Soviet Union?' He presented his findings on how scientists and environmentalists tried to protect nature in the Soviet Union. He conceded that they were 'not terribly influential or effective', but concluded that environmental activists 'created a bright haven in a gloom-washed land and set a standard of courageous collective behavior when that was a rarity'. ${ }^{33}$ Drawing on all the case studies from around the world, the introduction to the volume, however, argued that whereas in some societies, anti-modernists were able to shape a counter narrative that recast the terms of the debate about 'progress', or policies were introduced that 'put a halt to unchecked development without prohibiting economic development', on the other hand, the 'most disastrous failures attributable to highmodernist arrogance during the twentieth century occurred in the communist states'. Thus, for readers of this volume, the global comparative framework highlighted the importance of political systems, ideas and access to resources. ${ }^{34}$

30 Kenneth Pomeranz, 'Introduction', in Burke and Pomeranz, The Environment and World History, 27.

31 www.h-net.org/reviews/showpdf.php?id=26362, accessed August 2017.

32 Weiner, 'Predatory Tribute-Taking State', in Global Environmental History: An Introductory Reader, ed. J. R. McNeill and Alan Roe (London: Routledge, 2013), 283-319.

33 Douglas R. Weiner, 'Environmental Activism in the Soviet Context: A Social Analysis', in Shades of Green: Environmental Activism Around the Globe, ed. Christof Mauch, Nathan Stoltzfus and Douglas Weiner (Lanham, MD: Rowman and Littlefield, 2006), 101-34.

34 Mauch, Stoltzfus and Weiner, 'Introduction', in Mauch et al., Shades of Green, 1-9. 
In recent years several edited volumes on environmental history have been published that include essays by specialists on Russia and the Soviet Union that make contributions to our understanding of global environmental history, rather than seek mainly to explain what was, or may have been, peculiar to Russia. In an essay on 'Russia and the Soviet Union' in an encyclopedia of world environmental history, Weiner, again, presented a more balanced assessment than his more polemical piece on tribute-taking states. He considered the landscape and natural resources, and how they have been used since early modern times, pioneering Russian scientific research on nature protection from the late nineteenth century and its development and application in the Soviet period, as well as Soviet economic development and its impact on the environment. His conclusion balanced 'success stories' of environmental restoration against the customary list of disasters, but argued that the latter outweighed the former. ${ }^{35}$

The location of Weiner's essays in volumes with global coverage has allowed the Russian/Soviet experience to form part of wider analyses, highlighting both the widespread view of the particularly harmful impact of economic policies of communist states, China as well as Russia, but also other aspects of the story, such as the long history of nature conservation based on scientific ideas in Russia.

\section{The emergence of more balanced interpretations}

While some studies by individual specialists on Russia that have come to the attention of global environmental historians have presented a particular, and largely negative, interpretation that has reverberated in wider histories, the cause of presenting a more balanced interpretation of Russian and Soviet environmental history has been better served by some of our leading environmental historians (although some have occasionally revealed surprise that there may be more 'positive' aspects to the story) writing at the start of the present millennium as memories of the Soviet Union were starting to recede into history.

The author of a major study of world environmental history in the twentieth century, McNeill, included many examples from the Russian and Soviet states, as well as much of the rest of the world, to support his conclusion that 'to an unprecedented degree humankind in this [i.e. the twentieth] century has ... refashioned the earth's air, water, soil, and biosphere'. He included a familiar list of Soviet environmental impacts and catastrophes, such as the industrial pollution of the land, water and air; space junk; big dams; the desiccation of the Aral Sea; soil erosion as a result of the Virgin Lands Programme on the semi-arid steppe of Kazakhstan and elsewhere in

35 Douglas R. Weiner, 'Russia and the Soviet Union', in Encyclopedia of World Environmental History, ed. Shepherd Krech III, John R. McNeill and Carolyn Merchant (New York and London: Routledge, 2004), 3:1074-80. 
the 1950s; Soviet whaling from the 1940s; the Chernobyl explosion; and the threat to Lake Baikal. ${ }^{36}$ However, he presented balanced interpretations of the contribution of the Soviet Union to the refashioning of the environment. He noted the success of Soviet public health programmes between the mid-1920s and 1970s, which he attributed to the Soviet Union as a 'well-ordered society'. He offered an instructive conclusion, and one that showed his own preconceptions, concerning the US and Soviet governments' respective responses to scientific studies in the 1960s that revealed the health hazards of leaded gasoline. In the United States, the automotive and chemical industries prevented laws regulating it until the 1970s, but '[s]imilar findings in the USSR resulted in a ban on leaded gasoline in major cities in 1967, a rare instance of the Soviet Union leading the world to a healthier environment'. Elsewhere, McNeill noted: 'Geopolitical anxiety or ambition in particular helped spur Germany, Japan, Russia, China, Brazil and other polities to industrialize as quickly as possible, almost regardless of the consequences.' The results were air pollution and violence, and the lives and health of millions were sacrificed in the 'national interest'. Economic growth, he pointed out, was pursued by communists, nationalists and capitalists. He offered an insightful conclusion on the environmental impact of the autarchic economic policies pursued by the vast communist states of the Soviet Union and China, explaining how by combining all main areas of economic activity inside their borders, rather than relying on international trade for some of them, they suffered environmental degradation of their air, water and land. In poorer countries, in which he included Russia, he noted that environmental protection laws existed only on paper. ${ }^{37}$ Overall, therefore, McNeill offered a balanced if more negative interpretation of the role of the Russian and Soviet lands in the environmental history of the twentieth-century world.

In his ambitious and widely used environmental history of the world, Donald Hughes selected his case studies from around the globe. The study he took from Russia or the Soviet Union came, perhaps not surprisingly, in his section on 'Modern Environmental Problems': the disturbing consequences of the Chernobyl nuclear power plant explosion on the health of the population of the nearby region of Bryansk. He referred to other examples of Soviet environmental disasters, or neardisasters, such as the drying-up of the Aral Sea after water from the rivers feeding it were used for irrigation, the plan to divert rivers from Siberia and the Far North to replenish it, which was cancelled after protests from scientists, and the threat to the pristine waters of Lake Baikal from industrial pollution. He took care, however, to locate examples of human impact on the environment in the Soviet Union, such as the construction of high dams, deforestation, acid rain or factory fishing, in comparison with similar cases elsewhere in the world. He concluded that in Russia after the

36 J. R. McNeill, Something New Under the Sun: An Environmental History of the Twentieth Century World (New York: W. W. Norton, 2000), 26, 29-30, 32, 59, 86, 89, 115-16, 150, 162-6, 214-15, 240-2, 312-13, 330.

37 McNeill, Something New, 200, 204, 62, 116, 324, 333-4, 343. 
Bolshevik revolution, it might have been expected that environmental conditions would be better than in the capitalist world, since Marxist and socialist theory taught that nature be managed for the benefit of society. 'In reality,' he concluded, 'economic and political priorities took the upper hand, since Soviet planners insisted that socialism should out produce capitalism.' He continued: 'In practice, Russia and other communist states devastated the environment in a race for higher levels of production. Their record was at least as bad as that of the capitalist countries, if not as far-reaching.' While focusing on environmental degradation in the Russian and Soviet lands, Hughes nevertheless reached a balanced view in his global perspective, rather than a blanket condemnation. He also noted that observations from space since the launch of the first Soviet satellite, Sputnik, in 1957 had contributed to an awareness of climate change. ${ }^{38}$

At around the same time as McNeill and Hughes were writing, German scholar Joachim Radkau produced a global history of the environment that stretched far back in time as well as around the globe. He included several examples from Russia/ the Soviet Union in a global, comparative perspective. For example, he compared extensive and wasteful cultivation of land until it was exhausted in the Russian Empire with analogous practices in North America. Most of his examples from Russia were from the twentieth century. He wrote about 'colonial style' treatment of the environment in Central Asia and other outlying parts of the Soviet Union under Khrushchev in the 1950s and early 1960s. His account included the customary list of environmental disasters, real and potential: the Aral Sea, the aborted river diversion scheme, pollution of Lake Baikal, Chernobyl, and also the Soviet part in global phenomena, such as dam construction. In placing Soviet environmental history in a global perspective, like other scholars, he concluded that the Soviet ambition of overtaking the West led to environmental degradation, including ruthless treatment of the soil. He added, however, that this was in spite of pioneering Russian research on erosion control. He also noted that the 'Soviet Union was ... the first country where nature protection sought to avail itself of the authority of science'. He perhaps betrayed his preconceived ideas, however, by including the words 'surprisingly enough' in the middle of this sentence. ${ }^{39}$

A global study of environmentalism by the Indian scholar Ramachandra Guha devoted a chapter to 'socialism and environmentalism'. Drawing in particular on the monographs by Weiner, Guha contrasted Soviet Marxist indifference to nature and the desire to exploit natural resources for economic growth with the growth of the scientific conservation movement in the Soviet Union in the 1920s. He argued

38 J. Donald Hughes, An Environmental History of the World: Humankind's Changing Role in the Community of Life, 2nd ed. (London and New York: Routledge, 2009) [1st ed. 2001], 206-12, 156, 160, 188, 191, 192, 231, 259.

39 Joachim Radkau, Nature and Power: A Global History of the Environment (Cambridge: Cambridge University Press, 2008) [first published in German in 2002, but revised for translation], 183, 184, 254, 256, 257, 271-2, 275. 
that the Russian scientific understanding of protected areas (zapovedniki) was 'more sophisticated' than in the United States, where national parks had been established for 'cultural and nationalist reasons'. In line with conventional narratives, Guha argued that Stalin's first Five-Year Plan of 1928-32 for industrial and agricultural development signalled the 'demise of Soviet environmentalism'. The expression of environmentalist views was sharply curtailed as economics trumped nature protection. The greater openness under Gorbachev in the late 1980s allowed the emergence of a new environmentalism and protests against the consequences of unchecked industrialisation, the pollution of Lake Baikal and environmental disasters such as Chernobyl. Guha's chapter on socialism also included discussion of China and eastern Europe in similar terms. ${ }^{40}$

\section{Longer-term perspectives}

While the studies by McNeill, Hughes, Radkau and Guha gave more balanced assessments of Russian and Soviet environmental history than the other accounts discussed earlier, the more negative elements reflected the emphasis on the twentieth century by all four authors. On the other hand, global environmental historians who have taken a longer-term perspective and, perhaps significantly, have availed themselves of expertise on Russian environmental history, have presented interpretations that view Russia as part of wider, global processes, rather than as an example of 'exceptionalism' in which the environment has suffered particularly badly.

Taking pride of place in this regard, and setting a very high standard for such studies, John F. Richards wrote an excellent analysis of the 'environmental history of the early modern world', from 1500 to 1800 , through the lens of a series of case studies of expanding frontiers that allowed humans to use more land and natural resources. The book is truly global in scope, with case studies of Taiwan, China, Japan, the 'British Isles', South Africa, the West Indies, Mexico, Brazil, eastern North America and the seas and oceans. Richards included studies of frontier settlement in Russia, in particular the forest-steppe and steppe, and of the hunt for furs in Siberia. Although he relied on works in English and other western European languages, he took the trouble to consult specialists on each of the regions he selected for his case studies, including Russia and Siberia. These two case studies present a picture of interaction between peoples, environments, states and neighbouring states. The notion of environmental determinism that has underlain, and misdirected, many older studies of the Russian lands was not mentioned. He discussed human impact on the environment throughout the book, and did not make, or consider, a case for Russian exceptionalism. In his conclusion, he described trends across Eurasia,

40 Ramachandra Guha, Environmentalism: A Global History (New York: Longman, 2000), 125-37. 
and did not single out Russia. Rather, the exceptions he noted were changes in the conservation of resources in Tokugawa Japan and moves to new sources of energy in parts of north-western Europe. One of many advantages of Richards' global perspective is that it drew attention not to alleged 'backwardness' or misuse of resources in some parts of the world, such as Russia, but instead to regions in east Asia and north-western Europe where there were changes that were exceptions to much of the rest of the world. ${ }^{41}$

There are a few other examples of such global studies that consider examples from Russia and the Soviet Union in a balanced manner. Stephen Mosley's concise book on the environment in world history, that covers a much longer period of time than Richards in a much shorter space, simply includes examples from Russia in discussions of wider trends, and not as examples of egregious mismanagement of resources. ${ }^{42}$ Martin Rudwick's analysis of the discovery of earth's deep history acknowledges the important contributions by Russian and Chinese scientists' studies of fossils in Siberia and China from the 1970s in understanding the Cambrian 'explosion' of life. ${ }^{43}$

When the environmental history of Russia is presented over a longer time period, not focusing mainly on the Soviet period, then a different picture emerges: not of exceptionalism, which may in part have been fuelled by preconceptions, but as part of wider, longer-term, global developments. Thus, the phases of writing about Russian environmental history mirror phases two and three in John MacKenzie's interpretation of writing on environmental history from an 'apocalyptic approach' to a new 'perspective school' with longer time frames. ${ }^{44}$

\section{The integration of different voices from specialist Russian environmental historians in global environmental history}

While Weiner and Josephson, two of the first American specialists on Russian environmental history, served for a long time as the face of the subject to the wider world of global environmental historians, their interpretations-which are entirely legitimate- have emphasised the negative, declensionist, side of the story that has to a large extent shaped wider understandings of the complex entanglement between

41 John F. Richards, The Unending Frontier: An Environmental History of the Early Modern World (Berkeley, CA: University of California Press, 2003).

42 Stephen Mosley, The Environment in World History (London: Routledge, 2010).

43 Martin J. S. Rudwick, Earth's Deep History: How it was Discovered and Why it Matters (Chicago, IL: University of Chicago Press, 2014), 277.

44 John M. MacKenzie, Empires of nature and the nature of empires: Imperialism, Scotland and the environment: the Callander lectures, delivered in the University of Aberdeen, 2-7 November 1995 (East Linton: Tuckwell, 1997). 
people and the non-human world in this part of the globe. Both, moreover, have worked mostly on the Soviet period, for which the negative interpretation may well be most appropriate. Weiner, moreover, read back from the twentieth century to construct a longer-term negative interpretation. A significant step forward in the presentation of differing and competing interpretations has been the integration of more specialists on Russian environmental history with different voices in global environmental histories. It is significant, moreover, that these newer spokespeople on Russia to global environmental historians have tended to be specialists on earlier periods or longer time frames. It is extremely important, furthermore, that some Russian-trained Russian scholars with international experience, knowledge of the wider literature, and command of English are contributing to global studies. It is also worth pointing out that while environmental historians elsewhere in the world have not rushed to study Russian environmental history, specialists in the field in Russia have endeavoured to read, and to publish in Russian translations, some of the works of leading environmental historians from other parts of the globe. ${ }^{45}$

In a multi-volume global history of water from ancient times to the present, two Saint Petersburg-based scholars contributed an essay on the significance of the River Neva in the history of their home city and country. Their essay considered the role of the river and the transport infrastructure it provided in the decision to locate a city in the extreme north-west of Russia, the river's influence on the spatial organisation of the city, and obstacles to the city's construction presented by the river, such as frequent floods. The authors concluded not that humans had 'conquered' and degraded the river, but that 'people learned to live near the Neva River using its resources and trying to escape its potential threats', and that the 'Neva, a wild and self-willed river, became [an] inalienable part of the regular and predictable everyday life of millions of people'. ${ }^{46}$ The editors' introduction, moreover, presented their study of the Neva as 'telling a similar story' to studies of the River Edo in the Kanto region of Japan and the rivers flowing into the lagoon at Venice; in other words, a case study in Russia as part of a global story, not an example of exceptionalism. ${ }^{47}$

In contrast to the environmental histories of European colonialism and imperialism referred to above that focused on the overseas colonies of western Europe's maritime empires, one such volume did include an essay on a part of Russia's land empire. Julia Lajus contributed - or perhaps more importantly was invited to contributean essay on the 'Colonization of the Russian North' to a volume on 'cultivating the

45 See the collection of Russian translations of essays by scholars such as John McNeill, William Cronon and Alfred Crosby: Chelovek i priroda: ekologicheskaia istoriia, ed. Daniel Aleksandrov, Frants-Iosef Briffemaier and Iu. Laius (St Petersburg: Aleteiia, 2008).

46 Alexei Kraikovsky and Julia Lajus, 'The Neva as a Metropolitan River of Russia: Environment, Economy and Culture', in A History of Water, vol. 2: Rivers and Society: From Early Civilizations to Modern Times, ed. Terie Tvedt and Richard Coopey (London: I.B. Tauris, 2010), 343-68.

47 Terie Tvedt and Richard Coopey, 'A "Water Systems" Perspective on History', in Tvedt and Coopey, A History of Water, 2:18. 
colonies'. In her introduction, the editor remarked: 'Turning to a very different part of the world', Lajus's essay 'reminds us that the reach of colonialism extended not just to the temperate and tropical regions but northward to the Arctic and subarctic ones as well'. The editor, however, continued that the essay 'brings an unexpected part of the globe under the consideration of colonial history', suggesting that the environmental history of Russian colonialism was still seen as an outlier to global environmental histories of imperialism. ${ }^{48}$ To the best of the author of this article's knowledge, moreover, it is the only such volume on the environmental history of European colonialism and imperialism to include the Russian Empire. Other promising approaches to integrating the environmental history of Russia into global environmental histories are to take a comparative perspective, comparing similar environmental regions in different parts of the world, and a transnational approach considering exchanges between such regions. ${ }^{49}$

\section{Conclusion}

For too long, 'global environmental history' has not been truly 'global', but has been shaped by the perspectives, worldviews and linguistic skills of its practitioners, who have generally, but not solely, been based in the Anglophone world. Important exceptions considered here have been the books by Radkau, a German scholar, which is available in English translation, and the Indian scholar Guha. The former follows the Western-centric agendas of his Anglophone counterparts. The latter is more distinctive, and forms part of the major contribution by South Asian scholars to postcolonial understandings of global history. Moreover, and importantly from the perspective of this essay, in recent years, books and edited collections on global environmental history have started to pay more attention to Russia and the Soviet Union, and to present different, more balanced and broader interpretations of aspects of their environmental history that complement and supplement the more 'traditional' emphasis on the environmental damage caused by the Soviet state. In part this has been because such histories have looked back over longer time periods, and in part because more Russian environmental historians with an international outlook have contributed to such global studies. A key to understanding why this has taken so long is that environmental history in Russia and of Russia, to use

48 Karen Oslund, 'Getting Our Hands Dirty', in Christina Folke Ax, Niels Brimnes, Niklas Thode Jensen and Karen Oslund, Cultivating the Colonies: Colonial States and their Environmental Legacies (Athens, OH: Ohio University Press, 2011), 7-8; Julia Lajus, 'Colonization of the Russian North: A Frozen Frontier', in Ax et al., Cultivating the Colonies, 164-90.

49 See, for example, David Moon, 'The Grasslands of North America and Russia', in A Companion to Global Environmental History, ed. J. R. McNeill and Erin Stewart Maudlin (Chichester: Wiley-Blackwell, 2012), 247-62; David Moon, 'In the Russians' Steppes: The Introduction of Russian Wheat on the Great Plains of the United States of America', Journal of Global History 3 (2008): 203-25, doi.org/10.1017/s1740022808002611 (Russian translation: 'Introduktsiia russkoi pshenitsy na Velikikh Ravninakh Soedinennykh Shtatov Ameriki', Amerikanskii Ezhegodnik (2011): 161-76). 
Lajus's phrase, developed more slowly than in some other parts of the world, in particular the United States..$^{50}$ The reasons for this include different academic and disciplinary traditions in the Russian academic world, which have left a relatively limited space for environmental history to develop. Outside Russia, moreover, fewer scholars know, or have the opportunity to learn, Russian than other European or global languages, thus restricting the numbers that can read the specialist literature, undertake archival research and conduct interviews. ${ }^{51}$

The relatively slow development of the environmental history of Russia led to the persistence of views that little had been done on the subject. As recently as 2008, Radkau could write that 'Russian environmental history is still largely unexplored. This is paradoxical, since Russian science was a global leader in soil research far into the Soviet period'. ${ }^{52}$ Two years later, McNeill stated that 'Russia' was one of the 'geographic areas that, at present, [is] least well represented in the literature on environmental history'. He continued that it offered 'dramatic opportunities' for scholars. ${ }^{53}$ This may be contrasted with the earlier integration of the environmental history of another vast Eurasian state-China-into global environmental history. A possible explanation is the availability in English of major syntheses of Chinese environmental history. Mark Elvin's ambitious The Retreat of the Elephants, covering three millennia of China's environmental history, appeared in 2004. ${ }^{54}$ More recently, Robert Marks emphasised that his study of Chinese environmental history over the long term told 'a story that needs to be told, and understood, because of its profound implication not only for China but also for the world'.$^{55}$ Notwithstanding the endeavours of environmental historians of Russia and the Soviet Union, we are still waiting for a similarly accessible, ambitious and long-term study of their part of the world.

Over the last decade and half, however, environmental historians working in Russia and neighbouring countries, and on Russia around the world, have been catching up with their counterparts researching the environmental history of elsewhere on the globe. Participation by Russian environmental historians at the biennial conferences of the European Society for Environmental History (ESEH) has been increasing. At the 2017 conference in Zagreb, Croatia, there were 19 delegates from the Russian

\footnotetext{
50 Julia Lajus, 'Russian Environmental History: A Historiographical Review', in The Great Convergence: Environmental Histories of BRICS, ed. S. Ravi Rajan and Lise Sedrez (Oxford University Press, forthcoming). I am grateful to Dr Lajus for allowing me to see her forthcoming chapter.

51 See Theodore P. Gerber, 'The State of Russian Studies in the United States: An Assessment by the Association for Slavic, East European, and Eurasian Studies, July 2015'. iseees.berkeley.edu/sites/default/files/u4/FINALASEEES-assessment-report.pdf.

52 Radkau, Nature and Power, 183.

53 J. R. McNeill, 'The State of the Field of Environmental History', Annual Review of Environment and Resources 35 (2010): 366.

54 Mark Elvin, The Retreat of the Elephants: An Environmental History of China (New Haven, CT: Yale University Press, 2004)

55 Robert B. Marks, China: Its Environment and History (Lanham, MD: Rowman \& Littlefield, 2011), 7.
} 
Federation and Russians constituted the fourth-largest national group. ${ }^{56}$ These scholars are producing interesting work and also participating in international, and global, networks. The greater integration of Russian environmental historians into international organisations may be illustrated by Lajus, of the Higher School of Economics in Saint Petersburg, who served as vice-president of the ESEH from 2011 to $2015 . .^{57}$ There are now an expanding number of environmental historians in and of Russia, and a rich and growing literature on these lands and adjoining seas and oceans. This literature addresses many issues of interest to environmental historians around the world, from environmental protection and conservation, as well as pollution and degradation, to sustainable practices in agriculture, forestry, fishing and hunting, and cultural representations of landscapes. These and other works should, in time, be incorporated into global environmental histories and contribute to the further development of our understandings of the environmental history of the globe. Future global environmental histories should demonstrate the various and contrasting parts that have been played in it by the immense lands that have been ruled by Russia. ${ }^{58}$

56 ICEHO Bulletin 13 (July 2017): 6. docs.google.com/viewerng/viewer?url=http://eseh.org/wp-content/uploads/ ICEHO-Bulletin-13-Final.pdf, accessed August 2017.

57 eseh.org/about-eseh/board/pastboards/board-2013-2015, accessed August 2017.

58 Given the growing number of studies of Russian and Soviet environmental history, it would be unfair to single out a few examples. Instead, readers are referred to a number of recent articles surveying the field; for example: Andy Bruno, 'Russian Environmental History: Directions and Potentials', Kritika: Explorations in Russian and Eurasian History 8, no. 3 (2007): 635-50, doi.org/10.1353/kri.2007.0031; Brian Bonhomme, 'Writing the Environmental History of the World's Largest State: Four Decades of Scholarship on Russia and the USSR', Global Environment 12 (2013): 12-37, doi.org/10.3197/ge.2013.061202; Randall Dills, 'Forest and Grassland: Recent Trends in Russian Environmental History', Global Environment 12 (2013): 38-61, doi.org/10.3197/ge.2013.061203; Stephen Brain, 'The Environmental History of the Soviet Union', in McNeill and Mauldin, A Companion to Global Environmental History, 222-43; Stephen Brain, 'The Environmental History of Russia', Oxford Research Encyclopedias, published online November 2017, oxfordre.com/view/10.1093/acrefore/9780199389414.001.0001/acrefore9780199389414-e-355; and Lajus, 'Russian Environmental History'. For a bibliography of nearly 500 items in English on the topic, see: www.zotero.org/groups/271874/russian_environmental_history, accessed August 2017. A network of scholars from Russian, British and American universities participated in a three-year project (2013-16) 'Exploring Russia’s Environmental History and Natural Resources' funded by the Leverhulme Trust: www.york.ac.uk/history/research/majorprojects/russiasenvironmentalhistory, accessed August 2017. 
This text is taken from International Review of Environmental History, Volume 3, Issue 2, 2017, edited by James Beattie, published 2017 by ANU Press, The Australian National University, Canberra, Australia.

dx.doi.org/10.22459/IREH.03.02.2017.03 